Journal of Teacher Education for Sustainability,

vol. 14, no. 2, pp. 89-110, 2012

\title{
ICT-ENABLED CLIMATE CHANGE EDUCATION AND CHILDREN'S RIGHTS
}

\author{
Vassilios Makrakis, Dimitrios Gkotzos and Nikolaos Larios \\ University of Crete, Greece
}

\begin{abstract}
This paper deals with a web-based learning environment that introduces primary school learners into the issue of children's rights and climate change education. The methodological approach used is based on critical pedagogy and hypermedia technology. Through open source learning technologies and authentic learning activities that are enriched by open education resources and learning objects largely elicited from the Web, learners are being informed and construct knowledge related to six key areas of children's rights affected by climate change.
\end{abstract}

Key words: children's rights, climate change education, information and communication technology, education for sustainable development

\section{Introduction}

There is a widespread consensus among researchers that climate change is taking place bringing a number of risks and irreversible impacts on people and nature. Children and adolescents are among the most vulnerable social groups of any community, especially in less developed countries that will disproportionately suffer the negative effects of climate change (Hodge, 2010). Women are particularly affected because they are the largest percentage of the poor population (it is estimated that women account for $70 \%$ of poor people), and they also face gender inequalities, which climate change tends to exacerbate, as highlighted in the Human Development Report of the United Nations Development Programme (UNDP, 2007). Some of these inequalities are lack of access to resources such as land, credit and training, limited participation in decision-making processes, more dependence on natural resources and greater caring responsibilities (Agostino, 2010). In general, those most prone to suffer the effects of climaterelated hazards are often marginalised geographically (for instance, live in hazardous places such as informal settlements or in remote locations), socially (for instance, lack of social protection and health services), economically (for instance, lowincome people or resource dependent populations) and politically (for instance, people not giving them a voice and thus excluded from political and decision-making processes) (Gaillard, 2010). This resulted to 54 articles and two optional protocols of the Convention on the Rights of the Child (CRC) (United Nations [UN], 1989) that is the first legally binding international instrument 
to incorporate the full range of human rights (United Nations International Children's Fund [UNICEF], 2012). It includes the right to survival, to full development, to protection from harmful influences, abuse and exploitation and to increased participation in family, cultural and social life. Back and Cameron (2008), Stone and Lofts (2009) and United Nations International Children's Fund Innocenti Research Centre (UNICEF IRC, 2008) focus on the articles of the CRC that are relevant to children's rights affected by climate change. These are divided by UNICEF IRC (2008) into four categories: 1) child survival and child health; 2) education and equality; 3 ) emergencies and child protection and 4) empowering children to act. All these issues are seen as closely related to climate change. Children's survival and health are connected with Article 6 of the CRC (children's right to live and governmental safeguard of survival and healthy development) and Article 24 (children's right to good quality health care, safe drinking water, nutritious food, a clean and safe environment, information to help them maintain their health and provision for help from rich countries to poor towards the achievement of the above rights).

By agreeing to undertake the obligations of the Convention, national governments have committed themselves to protecting and ensuring children's rights. In an effort to increase the scale and effectiveness of EU action, the European Commission came forward with a crosscutting document, including internal and external policies on children's rights (Ruxton, 2005). In its Communication, seven specific objectives have been distinguished (European Unit, 2006):

- capitalising on existing activities while addressing urgent needs;

- identifying priorities for future EU action;

- mainstreaming children's rights in EU actions;

- establishing efficient coordination and consultation mechanisms;

- enhancing capacity and expertise on children's rights;

- designing a communication strategy on children's rights;

- promoting children's rights in external relations.

Through these short and long-term measures, the Commission hopes to promote universal children's rights worldwide, building on its tradition of legal and political commitments with regard to human rights in general and children's rights in particular.

The potential impact on children has been a critical missing element from the debate about climate change, despite the fact that there are several studies showing that the climate change impact on children is of critical importance. UNICEF (2009) identifies several reasons that make children particularly vulnerable to the impact of climate change. These include:

- the high risk of exposure to environmental hazards due to their stage of psychological and cognitive development;

- the fact that vector-borne diseases and under-nutrition (which are the main reasons of child mortality) are highly sensitive to climatic conditions;

- the fact that the world's least developed countries, which have the largest proportion of children's population and poor means to face extreme climatic events, will be mostly affected by climate change; 
- the intersection of climate change with social, economic and political strains, which result in children's psychosocial trauma, recruitment into armed forces, displacement and forced migration, which may in turn lead to family separation and exposure to trafficking and exploitation.

The United Nations Educational, Scientific and Cultural Organisation (UNESCO, 2009) has stressed the need to review and reorientate the present educational and teaching and learning programs in order to address the causes and consequences of climate change. Article 6 of the United Nations Framework Convention on Climate Change (UNFCCC) calls on countries to promote and facilitate education and public awareness of climate change. The International Alliance of Leading Education Institutes (IALEI) (2009) attempted to define climate change Education (CCE) pointing to two different positions regarding CCE. The one regards CCE as a natural sciences issue, whereas the other sees climate change as an integral part of sustainable development defined as a delicate balance between the human need to improve lifestyles and feeling of well-being and preserving natural resources and ecosystems, on which we and future generations depend (Global Development Research Center [GDRC], 2009). Plantilla (2006) refers to the UNDP classification of groups of human rights which are most frequently encountered in sustainable human development activities (Figure 1). Hence, these rights and issues could be deemed as closely related to education for sustainable development (ESD) and to CCE respectively. These issues are the following: food and health; land, language and culture; environment; labour and the workplace; children's welfare; education; women.

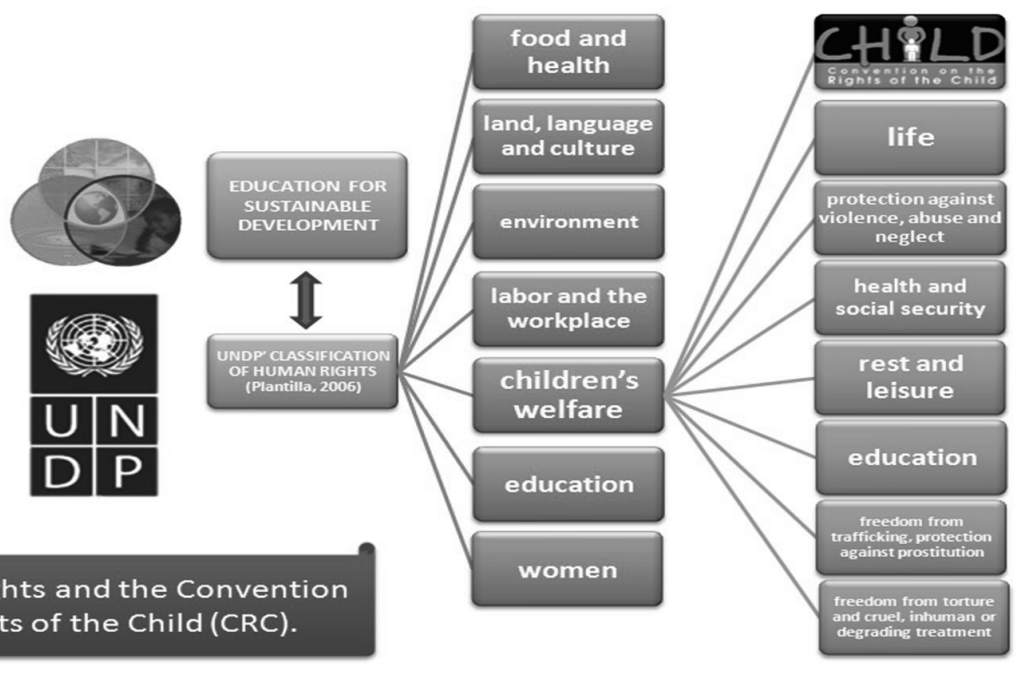

Figure 1. ESD, human rights and the Convention on the Rights of the Child (CRC)

CCE is also closely related to another United Nations (UN) initiative, the Millennium Development Goals (MDGs). Concerns are raised that climate change threatens the progress 
made toward meeting the Millennium Development Goals (MDGs). Therefore, investing in quality education to combat climate change is seen as an essential tool in achieving the MDGs. Figure 2 attempts to illustrate UNICEF's (2003) connection between MDGs and the priority areas of action of the "A world fit for children" agenda. Todaro \& Smith (2009) argue that the MDGs allocate specific responsibilities to the rich countries in an attempt to reduce the gap between them and the developing countries. At this point, it would be interesting to mention Sax's (2008) view that "basically all eight MDGs are more or less directly linked to the situation of children" (p. 1).

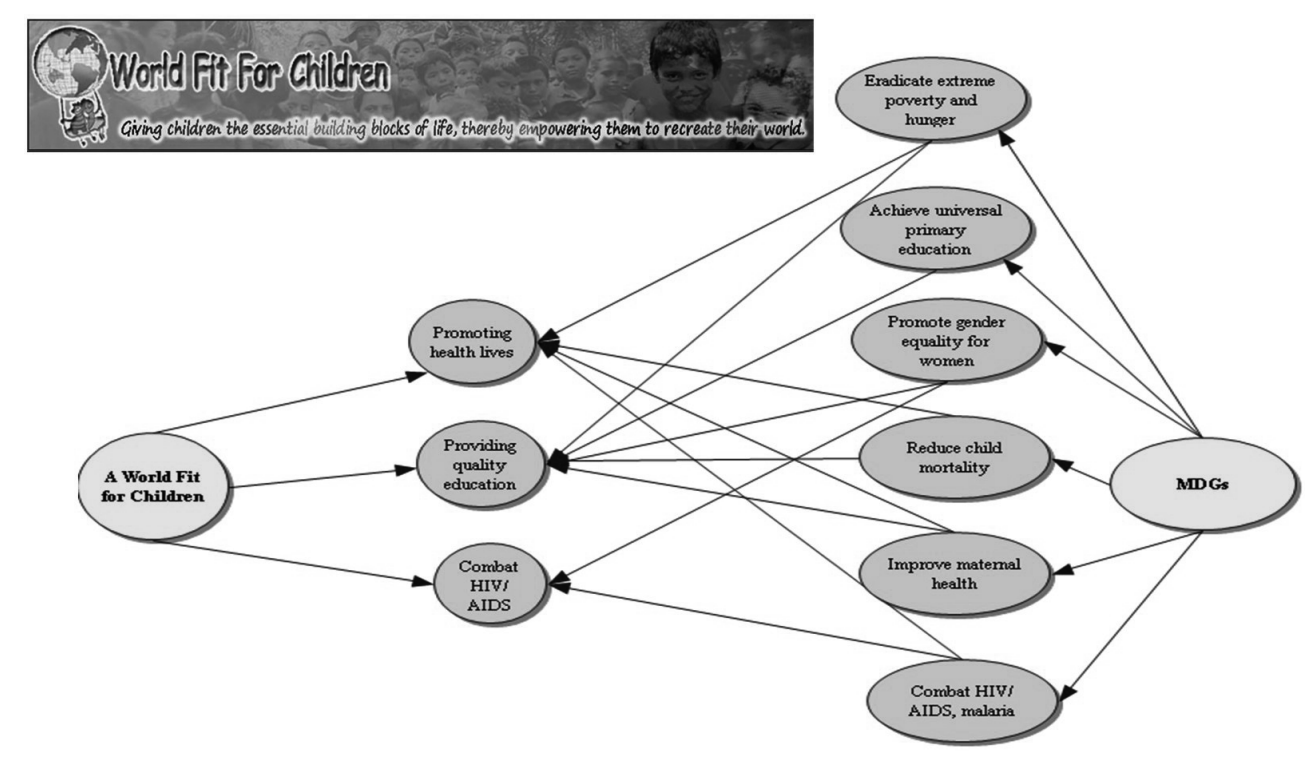

Figure 2. MDGs and "A world fit for children"

It can be argued that a child rights-based approach (Figure 3) to the integration of climate change into the school curriculum is of high importance. In such a context, CCE programmes should not only make children aware of the present environmental situation and its effect on their rights, but also actively involve them in child-centred as well as child-led activities (Arts, 2009). The implementation of such an approach could in its turn make children "potentially effective agents of change within communities to foster an appropriate approach to address climate change" (Tanner et al., 2009, p. 5). As Putnam (2009) argues, climate change is not just an environmental problem, but it is more a human rights issue. 


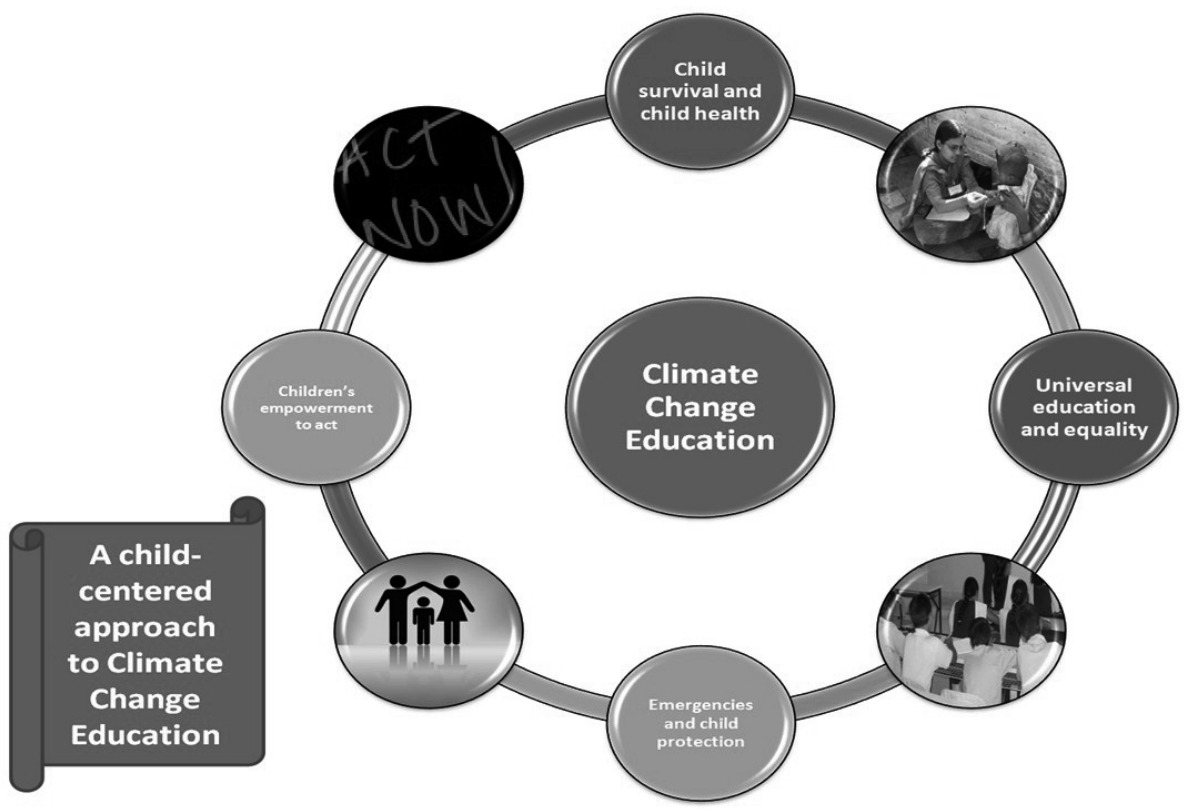

Figure 3. A child-centred approach to CCE

\section{ICTs as enabling tools for climate change and children's rights}

The increasing diffusion of information and communication technology (ICT), from interactive Web portals, Web 2 applications, educational TV, social media, text messages (SMS), community radio, mobile phone-based monitoring systems, geospatial information systems, among others, offers new mechanisms for advocacy, empowerment and capacity building in tackling issues related to climate change. Emergent experiences, particularly from developing countries, suggest the potential of ICT in face of the challenges posed by pervasive poverty, environmental degradation and climate change impacts (Ospina, 2012). In a review of the existing literature on ICT, climate change and development, Ospina and Heeks (2010) indicate that the potential of digital technology has not yet been integrated into a systematic understanding of adaptation and resilience, let alone from the perspective of a conceptual framework. However, for ICT to serve their potential for learning to transform oneself and society, there is need to view both ICT as a context to climate change education and the latter as a context for integrating ICT in the teaching and learning process. The recognition of ICT has also been extended in the Rio+20 World Summit. More specifically, the role of ICT is explicitly mentioned in regards to five key areas of action towards the achievement of sustainable development (Ospina, 2012). 


\section{ICT and multi-stakeholder engagement}

Article 44 of the outcome document that recognises the role of ICT facilitating the flow of information between governments and the public, enabling public engagement in sustainable development. The document calls for governments to work toward improved access to ICT, especially broad-band network and services, and bridge the digital divide, recognising the contribution of international cooperation in this regard.

\section{ICT, knowledge exchange and capacity building}

Article 65 of the outcome document acknowledges the potential of ICT to promote knowledge exchange, technical cooperation and capacity building for sustainable development. The article emphasises the role of these tools in fostering experiences and knowledge sharing in different areas of sustainable development in an "open and transparent manner".

\section{ICT, food security and sustainable agriculture}

With the aim of improving agricultural productivity and sustainability, Article 114 of the outcome document calls for government action to improve access to "information, technical knowledge and know-how, including through new ICTs that empower farmers, fishers and foresters to choose among diverse methods of achieving sustainable agricultural production".

\section{ICT and energy efficiency}

Article 128 of the outcome document recognises the need to improve energy efficiency and the role of energy-efficient technologies in addressing sustainable development and climate change goals, including energy efficiency measures in urban planning, buildings, transportation and the production of goods and services. These constitute areas in which ICTs have proven potential to reduce emissions through 'smart' applications (for instance, smart motor systems, smart logistics, smart buildings and smart grids).

\section{ICT and youth education}

Recognising the importance of youth education and of ensuring that education systems provide the tools to pursue sustainable development, Article 230 of the outcome document calls for a more effective use of ICT to enhance learning outcomes.

ICT can provide opportunities for learners to construct meaningful learning environments which can be applied to ESD such as: a) engaging and challenging learners; b) stimulating dialogue and social negotiation through new modes of social interaction; $c$ ) learning by exploring and discovering; d) doing and reflecting; e) constructing personal and collective representations of meaning and $\mathrm{f}$ ) supporting discourse in dealing with real-life problems (Makrakis, 2011). More specifically, ICT plays an important role in advancing CCE and ESD in three ways: a) by increasing access to educational materials about sustainability (for 
instance, via distance learning, educational networks and databases); b) by helping to promote new ways of interactive learning addressing sustainable development issues and c) by opening access to information and knowledge (Makrakis, 2008, 2010). ICT can help learners explore concepts, engage in problem-based and authentic learning, enhance meta-cognitive skills and present information using multiple media. All these are closely related to the goals, themes and learning objectives addressed by education for sustainability and CCE. While ICT can provide interactive mind/cognitive tools to support learning and develop new understandings and knowledge in areas of teaching and learning for sustainability, CCE themes integrated into the school curricula could provide a worthwhile context for ICT in education.

The back-end system of our ICT-enabled climate change education and children's rights learning environment is based on Drupal - an open source content management system (CMS) similar to platforms like Joomla and Moodle that offers a powerful and extensible framework for web-based teaching and learning. Some of the advantages in using a CMS as a back-end are low development time along with high reliability and a wide variety of useful tools for educators such as blog, forum, user groups, privacy options, rich user profiles and easy management. The ICT-enabled climate change education and children's rights learning environment is enriched through the elicitation of learning objects found in the Web, including texts, images, videos organised and classified in a hypertext mode, with nodes linked in various, also non-linear, ways. The main learning content is composed of learning objects (LOs). The authoring tool that was used to create the LOs is Adobe Flash. Each LO is constructed from various media assets, such as text, video, animation, charts and sound narration, all gathered under a simple graphic user interface, comprising a dynamic and adaptable learning environment. It is also supported through the integration of various ICT tools, such as concept maps (Text2Mindmap), spreadsheets (Zoho Sheet), presentations (280slides), paint tools (Pixlr), word processing (Zoho Writer), Venn diagrams (classtools.net). In developing this hypermedia learning environment, we used both ESD-based instructional design principles and software engineering methods.

\section{The curriculum structure of the hypermedia environment and its underpinning theory}

\section{Learning theory foundations: The ExConTra learning paradigm}

The structure of our hypermedia learning environment is based on the principles of the ExConTra learning paradigm as depicted in Figure 4 (Makrakis \& Kostoulas-Makrakis, 2012). 


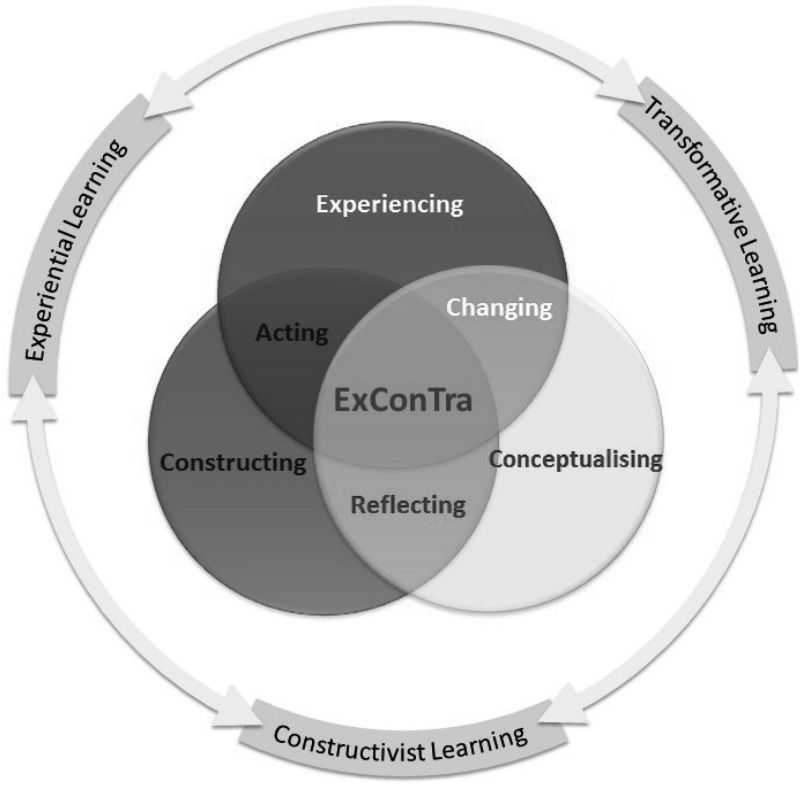

Figure 4. The ExConTra learning paradigm

Beginning with experiencing, learners identify a realistic and authentic task associated with a sustainable development issue, such as climate change and start collecting the information needed for their analyses, using various inquiry-based methods. To reduce the production of greenhouse gasses and in preparing societies for adaptability to risk and physical environmental change, climate change education needs to be experience-based and practice-centred. Learning-centred actions for changing unsustainable practices are needed (for instance, learning to implement energy saving measures), so that learners can experience and reflexively review their values and practices in climate change solutions. Through reflecting, self and/ or social, as well as through further reading and observing, learners organise and examine the collected data for the new experience from multiple perspectives in order to find meaning. For learners to make meaning, either individually and/or shared, they need to reflect on their own experiences, leading them to develop more abstract understandings of their experiences (conceptualising). Arriving at individual and shared meaning (constructing), learners need to get involved in a shared inquiry enriched through continuous reflection, reconceptualisation and active experimentation. In this sense, learning is an active and contextualised process of constructing meaningful knowledge based on one's own experiences, rather than acquiring it from someone else. Constructed knowledge and meaning is meaningful when it opens up opportunities for action. Merging knowledge and meaning with action (acting) implies a change agency and active citizenship. Acting as change agents, learners are empowered to transforming experience through critical reflection and active experimentation. When critical reflection is transformed into an action, it becomes praxis that turns learners able to transform 
oneself and society (transforming).

Central to the climate change processes of mitigation, adaptation and transformation are new values, creative thinking and problem-solving skills. These skills require learners to engage in critical analysis of causes and consequences and construct knowledge that may lead to action. This requires teachers involved in climate change education to integrate into their teaching and learning methodologies experiential, constructivist and transformative learning principles and values. Teachers need to shift from functioning as the sole source of information to becoming co-learners and facilitators using multiple sources of information and provide support and motivation in helping learners in the process of self-directed learning. Similarly, students' roles also need to change from passive recipients of climate change information to active learners who search, collect, analyse and interpret climate change data and collectively build up knowledge through inquiry and reflection.

\section{Curriculum structure: A theme-based approach}

A horizontal approach was adopted to organise curriculum that gives meaning to the scope and integration of curricular contents of different disciplinary areas and knowledge domains in a certain level of teaching (Makrakis, 2012). The following description introduces the function of this Web-based learning platform for each stage of thematic learning (Figure 5).

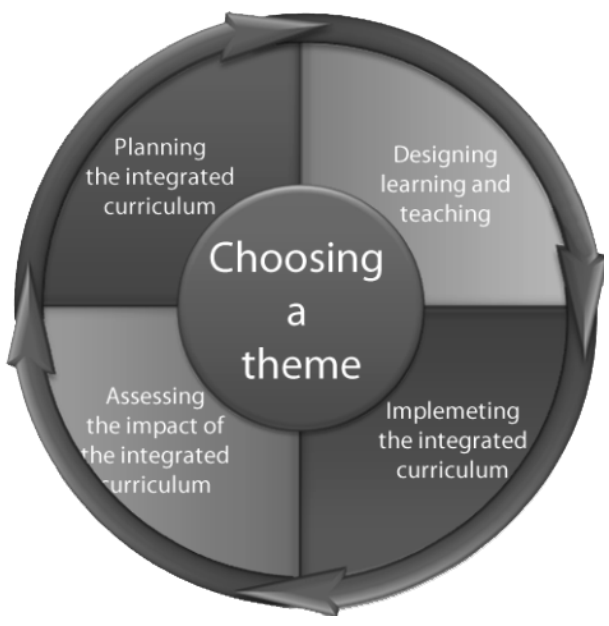

Figure 5. Steps in designing a theme-based instruction

Choosing a theme. This stage involves the choice of a large theme related to a compelling reallife issue, such as climate change which has meaningful connections in the broader framework of human experience that may connect family, school and community. In a recent study, it has found that web-based thematic learning: 1) has positive effects on learners' concept learning; 2) provides learners with a framework from which develop the related concepts in a more stable learning mode and 3) is suitable for students with different abilities (Liu \& Wang, 2010). 
Planning the integrated curriculum. In this stage, sub-themes, in the form of thematic areas, such as "Climate change and me", are planned to integrate concepts, skills and strategies that give meaning and direction to the whole learning process of climate change. The teachers involved organise the climate change core curriculum (both process skills and content knowledge) and sub-themes in an open and flexible way to assure student involvement at a later stage. Inter/cross disciplinary approaches are adopted in planning the integrated curriculum giving more emphasis in the processes involved rather than the outcomes. In web-based settings, a particular emphasis is given to a variety of interaction choices for participants: teacher-tostudent, student-to-student, student-to-resources and content. Additionally, a well-planned curriculum balances three types of activities: individual activities, small group activities and large group activities. By ensuring multiple channels of communication, engagement and collaboration within the design of a curriculum, providing a richly textured environment that can accommodate a full range of student needs and learning styles is of critical importance (Boettcher, 2007).

Designing learning and instruction. In a web-based learning environment, the learner interacts with the content, teacher and technology. This stage involves, first, the design of learning activities enabled by ICTs. Through designing learning activities suitable in web-based learning environments and driven by the ExConTra learning, the content becomes the means to an end and not an end in itself. In designing thematic learning and instruction, one approach that is consistent with the ExConTra learning principles is that a group of teachers can brainstorm learning activities using existing curriculum materials and be drawing directly from end-users' (teachers and students) ideas, interests and experiences during the formative evaluation process. In this process, involving community experts and other members could add value to designing meaningful and engaging learning activities. Strategies that ensure the reusability, adaptability and generalisability of teaching and learning materials should be planned.

Implementing the integrated curriculum. As pointed earlier, one of the most effective strategies for an integrated theme-based curriculum is to teach climate change in conjunction with mathematics, science, social studies, language arts, environmental studies and so on. This allows students to make connections between different areas as they explore a topic in detail and from a variety of approaches. Cross-curriculum projects allow students to see how knowledge and skills are connected in the various school subjects and how knowledge constructed and skills acquired can be transferred to other situations and real-life contexts. This step involves project-based learning as a model for implementing thematic learning activities. It is a shift away from the traditional classroom practices of short, isolated, teacher-centered lessons. Instead, it emphasises learning activities that are long-term, interdisciplinary, student centred and integrated with real-world issues and practices in which students plan, implement and evaluate projects that have real-world applications beyond the classroom. ICTs should be involved in such a curriculum in two ways. Firstly, technology can be used to support the instructional process, and, secondly, it should be a significant part of the content of 
the curriculum. The theme should provide a context for learning with ICTs and vice versa. Various ICT tools and Venn diagrams, like concept maps and semantic webs, help show the connection between related concepts and help learners explore meaningful learning experiences. Implementing the integrated curriculum in web-based learning settings with different tools and resources for retrieving content, using the online tools and facilitate interactions among teachers and students as well as other stakeholders, requires new instructional practices, such as peer tutoring, collaborative learning.

Assessing the impact of the integrated curriculum. In this stage, the focus is to determine the extent to which the curriculum plan that was implemented has achieved its goals and objectives as planned. The information collected from evaluating a curriculum forms the basis for making judgements about how successfully has the programme achieved its intended outcomes and the worth or value of the programme. This process can be integrated into three interlinked assessment levels: 1) diagnostic; 2) formative and 3) summative. The term diagnostic refers to a process at the initial phase; formative refers to a process while developing the curriculum so that revisions to it can be made and summative refers to a process at the end/after the curriculum programme is implemented. A critical concept applied to these processes is authentic assessment that is driven by ExConTra learning foundations. Authentic assessment to be incorporated in assessing the impact of the integrated curriculum include an amalgamation of tools and strategies that derive from ExConTra learning but also from objectivist learning theories if such tools contribute to the ExConTra learning principles. Among the most used tools include multiple choice tests with extended responses to help students become aware of their own thinking processes; observation; checklists; portfolios; concept mapping and Venn diagrams; scenario building; reflection and reflexivity; journalising; simulation; case-study analysis. All the three levels of assessment are interlinked, and, in a way, they provide a holistic framework for assessment. However, we consider formative assessment as the most critical process as it provides effective feedback and gives the opportunity for learners' and other stakeholders' active participation in the design and development of the integrated curriculum. Within this process, the use of concept maps and other structural knowledge representation techniques are very effective tools (Ahlberg, 2004; Trumpowe \& Shahzad Sarwar, 2010). The process of formative assessment should enable students to selfmonitoring progress; give regular feedback to students; support peer learning and assessment and design self assessment practice (Liang \& Kim, 2004). Visualisation tools, such as conceptual maps, help students process the abstract concepts or mental images that they depict, and the more they work designing materials, the more they construct their own meaningful realities based on new knowledge (Jonassen \& Reeves, 1996; Jonassen, Peck, \& Wilson, 1998).

\section{Curriculum areas of climate change education for children's rights}

We also adopted a human rights education approach that is based on empowering learners to differentiate between the charity dimension and other forms of aid. The structure of the "Children's rights and climate change" curriculum comprises six areas (Figure 6) integrated 
across the school curriculum of the primary education level (Figure 7):

1. Right to food and climate change.

2. Right to water and climate change.

3. Right to education and climate change.

4. Right to health and climate change.

5. Gender equality and climate change.

6. Right to environment and climate change.

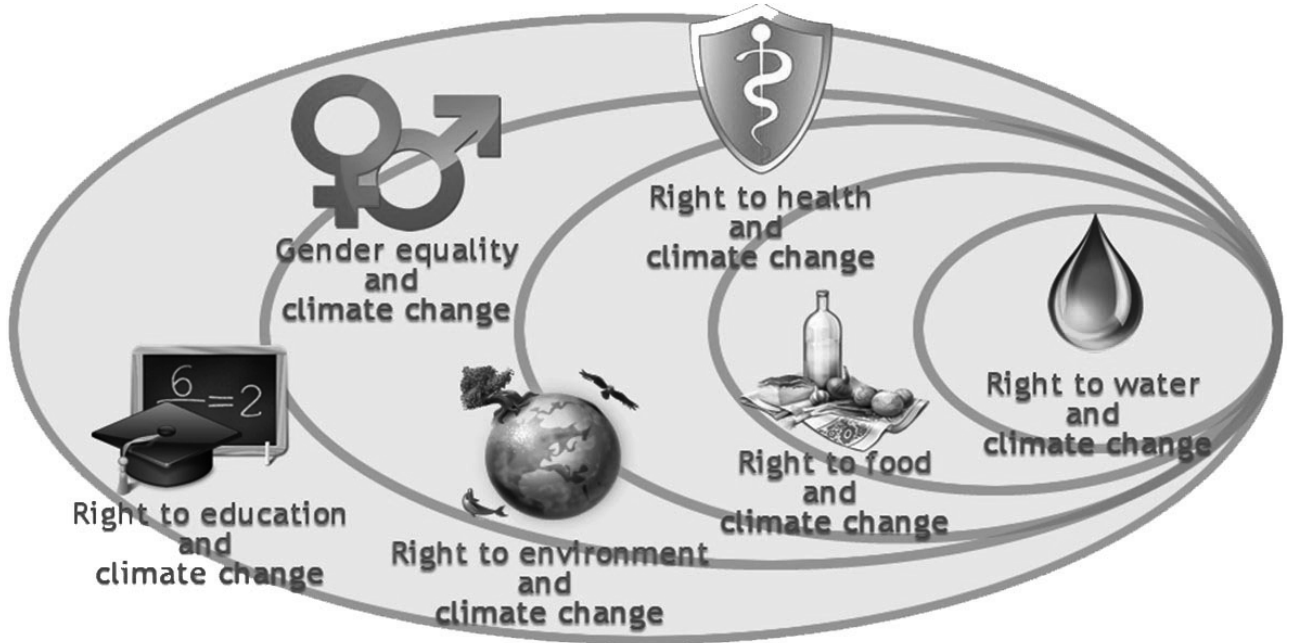

Figure 6: The content areas of the climate change education and children's right curriculum

We will deal with the first five, as the last one is in the process of development. These are designed to be integrated into the existing primary school curriculum from Form 4 to Form 6. In an integrated methodology, interdisciplinary topics are arranged around overlapping concepts and emergent patterns. This process blends the disciplines by finding overlapping skills, concepts and attitudes in a synergistic manner that makes the knowledge of one subject inseparable from that of another subject. These units together with the supportive web-based learning environment with its technologies can provide a good resource for the respective course "ICT, Climate Change and GIS/Geospatial Tools" of the M.Sc. programme within the framework of the ICT-enabled ESD project financed by the European Commission. 


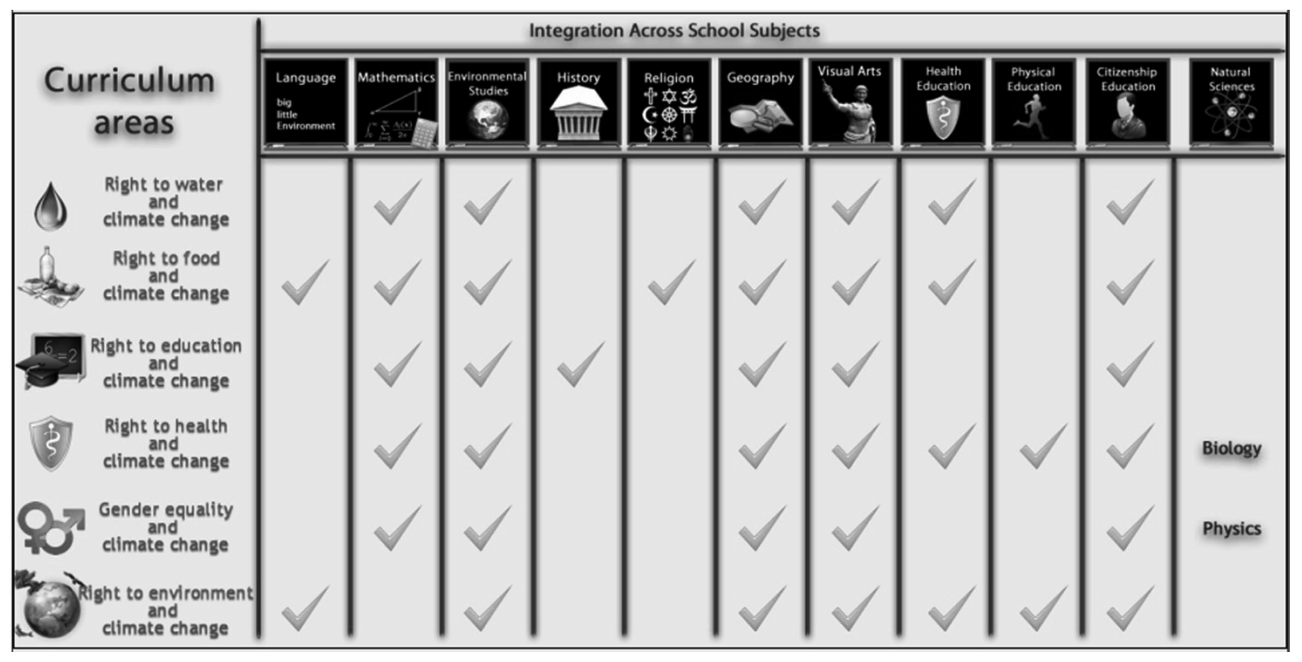

Figure 7. The cross-curriculum planning of the climate change education and children's rights curriculum

The learning environment (Figure 8) consists of the introduction and four units: a) Me and my food; b) Food as a basic need; c) Food as a right and d) Right to food and climate change. Access to these units is available through the top menu of the home page of the learning environment. At the left side of each page there is direct access to the basic tools of the learners (concept mapping, word processor, paint) as well as to a modern Greek online dictionary. The engagement of learners in the web-based learning environment starts with the exploration of learners' experiences about the concept of hunger. In the first unit entitled "Me and my food", learners' experience is explored through individual and group activities with which they are called to mention their nutritional habits and express their views regarding the foods that are necessary for our survival and growth. After the conceptualisation of the nutritional needs through the engagement of learners in various activities, they are asked to create their own meal plan by selecting themselves the kinds of food that it will contain. Then they share their constructed knowledge with their parents and encourage them to create a similar meal plan. At the end of the unit, learners working in groups are called to build a final concept map containing the foods which they believe are necessary for their survival and growth. 


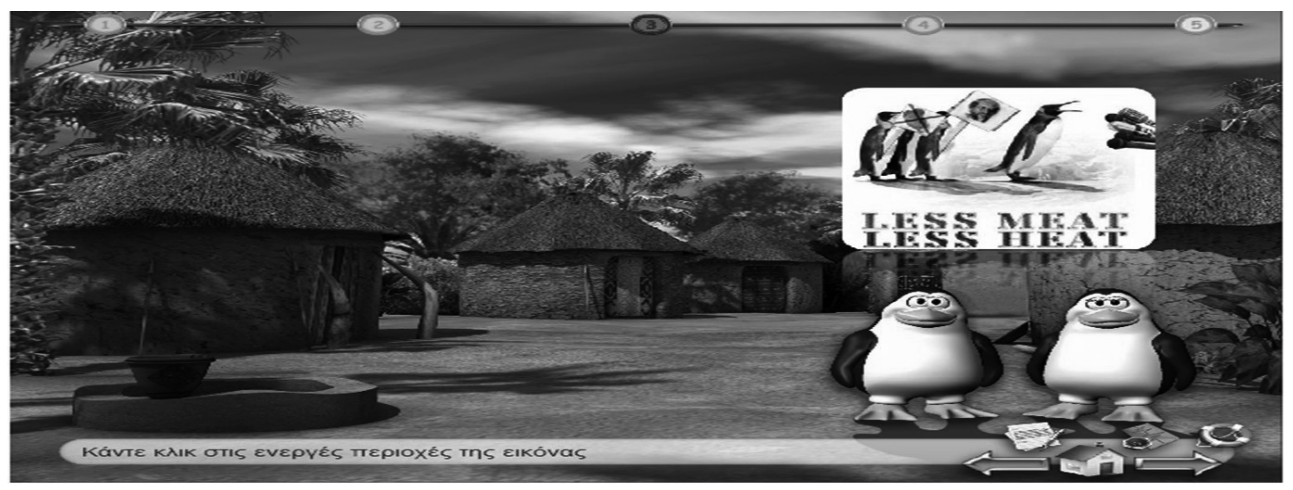

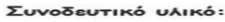
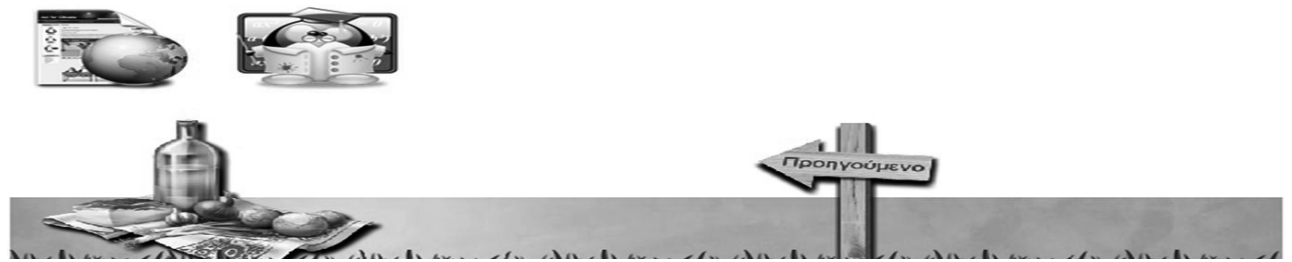

Figure 8. The learning environment

\section{Description of the curriculum areas}

\section{Right to food and climate change}

The right to adequate food is recognised in several international conventions. Food as a human right and basic need is the right of everyone to an adequate standard of living for themselves and their family. There is little doubt that climate change will accelerate grain sterility; accelerate erosion, desertification and reducing crop and livestock yields which will detrimentally affect the right to food of millions of people worldwide.

In the web-based hypermedia application entitled "Right to food and climate change", learners experience and conceptualise their nutritional needs while they are engaged in activities that lead to understanding food as a basic need and human right. Additionally, learners, through case studies activities, experience and conceptualise the way the denial of the right to food is related to some extreme local climate conditions which are due to the climate change phenomenon. Students are also asked to find ways of action in order to mitigate the climate change phenomenon and the shortage of food that derives from this phenomenon.

The unit "Food as a basic need" aims to make learners understand how important nutrition is for human survival, making a connection to food as a basic need and human right, in particular with children's rights. During the experiential phase, learners embedded advertisement videos about food. Learners' groups reflect upon the four groups of rights, the so called four pillars of the CRC and are asked to decide in which group the right to food should be 
included. In order to understand the importance of this right, learners are called first to calculate the number of people in the world who are denied the right to food and to consider the consequences of that denial. As a case study, we selected the Horn of Africa Peninsula, an area in which a great amount of the population is malnourished. In the next unit entitled "Right to water and climate change", Pakistan is examined as a case study in comparison with the previously examined case study of the Horn of Africa Peninsula. Through this comparative examination, learners' groups are asked to explore the similarities and differences between these two areas which have a high percentage of malnourished inhabitants. Through the study of selected texts and critical reflective questions, it is attempted to motivate learners to conceptualise the relationship between the denial of the right to food and some extreme local climate conditions that have arisen as an effect of climate change. Then, learners' groups are asked to use their constructed knowledge in order to find ways of action with which they could mitigate the climate change phenomenon and the denial of the right to food that is caused by the effects of this phenomenon. At the end, learners' groups are called to reflect upon all the previous activities and share their knowledge by making a presentation for a healthy and environmentally responsible nutrition.

\section{Right to water and climate change}

As the earth gets warmer, there will be lower and more erratic rainfall, which will exacerbate the already existing problems related to water supplies and access. The "Right to water and climate change" unit aims to make learners understand that access to drinkable water is a need which they have the right to fulfill as well as to encourage them to get involved in actions for the protection of this right. Additionally, learners, through case studies activities, are experiencing how the denial of the right to water is related to some extreme local climate conditions which are due to the climate change phenomenon. The web-based learning environment consists of the introduction and five units: a) restrictions of access to drinkable water; b) cost of access to drinkable water; c) climate change and drinkable water in the Mediterranean countries; d) over-consumption of water and e) pollution of the hydrographic network.

Through open source learning technologies and authentic learning activities that are enriched by open education learning objects elicited from the World Wide Web, learners explore limited availability of drinkable water and the number of people worldwide that are denied the right to water and conceptualise the effects that this denial could have. During conceptualisation, learners are also directed to consider the cost of drinkable water consumption. Learners also experience and conceptualise the effects of climate change phenomenon in the availability of drinkable water in the Mediterranean countries. Finally, we attempt to empower learners to take action regarding the protection of their right to drinkable water. This is accomplished through activities that involve not only climate change, but also the two other main causes for the limitation of the availability of drinkable water: over-consumption of water and the underground water pollution. In the unit entitled "Restrictions of access to drinkable water", learners' experiential learning starts with the number of people worldwide 
that are denied of this right. Then, learners conceptualise the effects that this denial could have. In the last two units, learners conceptualise two other factors that influence the availability of drinkable water: its over-consumption and water pollution. In the last unit, they reflect upon Asopos' river pollution as a case study.

\section{Right to education and climate change}

Education is a human right for everyone. The thematic area of education as a human need and right is explored in the "Right to education and climate change" unit. Learners are experiencing how the denial of the right to education is related to some extreme local climate conditions, which are due to the climate change phenomenon. It consists of the introduction and four units: a) education as a basic need, b) education as a right, c) right to education and climate change and d) right to education and local action. In particular, learners are encouraged to get involved and act locally in an attempt to overcome the obstacles that limit the provision of education to children locally as well as globally, with a particular focus on those obstacles related to the effects of the climate change phenomenon.

The engagement of learners in the web-based learning environment starts with putting them to experience a hypothetical situation in which they would have to live in a deserted place where there would be no school. Thus, learners are engaged in the unit titled "Education as a basic need" and are asked to conceptualise the impact that this lack of school would have in their life. Then, by solving simple mathematical problems, they experience and conceptualise the ways in which school is beneficial for our life as well as the extent to which education is denied to people globally,. Learners then study the case of 1goal campaign that was organised by the International Federation of Association Football (FIFA), UNESCO and ActionAid. They are watching an advertisement of this campaign which helps them transform their learning and see education not only as a need, but as a right. Thus, learners are engaged in the unit entitled "Education as a right". Learners' groups are reflecting upon the provisions of the CRC and are called to conceptualise the relation of some articles of the Convention to education. They are provided with online text and multimedia material. Then, learners are experiencing the extent to which the right to education is fulfilled globally (focusing on Nigeria as a case study) and locally. In their local study, they are also called to reflect upon the provision of education in Greece nowadays and in the past. Learners' parents and grandparents are engaged in this comparative reflection. Learners also conceptualise the factors that are affecting the right to education and the experiences about the relation of education to climate change. Tanzania and Poland are explored as case studies of climate change impacts on education. Through these case studies, learners divided into groups are asked to use their constructed knowledge and find ways of action with which they could mitigate the climate change phenomenon and the denial of the right to education that is caused by the effects of this phenomenon.

In the campaign "Schools as protectors of children" organised by UNICEF, Greece is suggested as a possible way of action that engages learners in the concluding unit of our 
intervention entitled "Right to education and local action", in which learners are conceptualising the main factors that restrict the right to education in Greece, with child labor being one of the most severe ones, and then they are asked to apply their constructed knowledge in order to find ways of further personal involvement and action with the aim to protect the right to education for all the children locally as well as globally.

\section{Right to health and climate change}

Climate change poses significant risks to the right to health for millions of people worldwide through the spread of a wide range of diseases. In the unit entitled "Right to health and climate change", learners experience and conceptualise their health needs while they are engaged in activities that lead to understanding health as a basic need and human right. Additionally, learners, through case studies activities, experience and conceptualise the way that some diseases are related to some extreme local climate conditions which are due to the climate change phenomenon. They are finally asked to find ways of action in order to intervene in this relation. The learning environment consists of three units: a) Health as a basic need; b) Health as a right and c) Right to health and climate change.

The engagement of learners in the web-based learning environment starts with the exploration of learners' experiences related to the concept of health. In the first unit entitled "Health as a basic need", learners' experience is explored through individual and group activities in which they are called to express their views regarding health self-protection. In addition, they explore in which ways health care is provided by the state. Through reflective activities, is the learners attempt to identify the main factors influencing our health. Learners then study the Declaration from the international conference on primary health care, in AlmaAta, September 1978, which expressed the need for urgent action to protect and promote the health of all, believing that it is a fundamental human right. Thus, learners are engaged in the unit entitled "Health as a right". Learners' groups are reflecting upon the provisions of the CRC and are called to conceptualise the relation of some articles of the Convention to health. Moreover, they are given material to study, which helps them to construct knowledge regarding the relation of the right to health with the rights to food, water and education, which were examined in the previous units. Malaria is explored as a case study of the climate change impacts on this vector-borne disease. Through these case studies, learners divided into groups are asked to use their constructed knowledge and find ways of action with which they could mitigate the climate change phenomenon and the denial of the right to education that is caused by the effects of this phenomenon.

\section{Gender equality and climate change}

Climate and gender issues are inter-related for several reasons. Women and men affect the climate in different ways. The European Institute for Gender Equality (EIGE) (2012) has published a report on gender equality and climate change which covers all the European Union 
member states and provides comparable data on the European Union level. The findings demonstrate that women's involvement in climate change decision-making at national, European and international levels is still low.

The unit entitled "Gender equality and climate change" aims to make learners able to understand that certain inequalities exist between men and women and that these inequalities are intensified by the effects of climate change. It also attempts to make learners understand that they have the right to be treated equally, irrespective of their gender, as well as make connections between gender equality and the children's rights which are reviewed in other units of the learning environment. The web-based learning environment consists of the introduction and five units: a) Women in society; b) Gender equality as a right; c) Gender equality and climate change and d) Gender equality and children's rights. When learners enter the web-based learning environment, they first experience the problem of illiteracy around the world and the fact that it mostly involves women. In the first unit entitled "Women in society", learners experience women's position at work and in social and political life and they conceptualise the existing inequalities between women and men.

The unit "Gender equality as a right" aims to make learners understand that all people should be treated equally irrespective of their gender. Learners experience the situation of women in several places around the world. In the next unit entitled "Gender equality and climate change", Senegal is examined as a case study. Through the study of selected texts and critical reflective questions, it is attempted to motivate learners to conceptualise the relationship between gender equality and some extreme local climate conditions that have arisen as an effect of climate change. In the last unit entitled "Gender equality and climate change", learners' groups are asked to use their constructed knowledge in order to make connections between gender equality and other children's rights. The aim is to make learners understand the extent to which the protection of other children's rights is related to gender equality and thus to motivate them to actively participate in actions for protection of their rights irrespective of gender.

\section{Concluding remarks}

Many poor people already live in fragile climates where food, health, education and clean water are scarce - climate change will exacerbate this fragility. Our children, especially the poor, are already facing a dismal future which appears to be even more detrimental. The potential impact on children has been a critical missing element from the debate about climate change. Increasing awareness, constructing new knowledge and generating action should be a priority that education should cope with. The web-based hypermedia environment on the issue of children's rights and climate change education presented in the previous sections can be used for enriching the primary school curriculum by integrating an education for a sustainable development perspective. Our learning environment adopts a child rightsbased approach to the integration of climate change into the primary school curriculum. The structure of our hypermedia learning environment is based on the principles of the ExConTra 
learning paradigm (experiencing, constructing, transforming), which empowers learners for active citizenship. Five of the six units were presented: right to food, water, education, health and climate change, as well as gender equality and climate change, as the last one is in the process of development. The activities integrated within this application are directly connected to the Hellenic primary school curriculum and in particular to the subjects of civic education, geography, mathematics, language and religion, as we adopt a cross-thematic and interdisciplinary curricular approach. A number of learning objects and ICT tools, largely elicited from the Web, have been used as scaffolds to advance the issues of food, water, education, health and gender equality as basic needs and human rights in connection to climate change education for sustainable development.

\section{Acknowledgement:}

This work has been developed within the framework of the ICTeESD project that has been funded from the European Commission (ERASMUS Multilateral Programme Virtual Campus Project No. 510212-LLP-1-2010-1-GR-ERASMUS-EVC (2010-3494). The content of the paper reflects the views of the authors, and the Commission cannot be held responsible for any use which may be made of the information contained therein.

\section{References:}

Agostino, A. (2010). Gender equality, climate change and education for sustainability. Newsletter for Beyond Access: Gender, Education and Development, 24. Retrieved August 12, 2012, from http://www.e4conference.org/wp-content/uploads/2010/02/Equals24.pdf

Åhlberg, M. (2004). Concept mapping for sustainable development. In A. J. Cañas, J. D. Novak \& F. M. González (Eds.), Concept Maps: Theory, Methodology, Technology. Proceedings of the First International Conference on Concept Mapping. Retrieved August 12, 2012, from http://cmc.ihmc.us/papers/cmc2004-233.pdf

Arts, K. (2009). A child rights perspective on climate change. In M. A. M. Salih (Ed.), Climate change and sustainable development: New Challenges for poverty reduction (pp. 79-93). Northampton, MA: Edward Elgar.

Back, E., \& Cameron, C. (2008). UNICEF UK climate change report. Retrieved August 14, 2012, from http://www.crin.org/docs/climate-change.pdf

Boettcher, J. (2007). Ten core principles for designing effective learning environments: Insights from brain research and pedagogical theory. Innovate, 3(3). Retrieved September 10, 2012, from http://www.innovateonline.info/index.php?view=article\&id=54

EIGE (European Institute for Gender Equality). (2012). Gender equality and climate change in the EU: Main findings. Retrieved September 10, 2012, from http://www.eige.europa.eu/ content/document/gender-equality-and-climate-change-main-findings

European Union. (2006). New EU strategy on children's rights. Retrieved August 20, 2012, from 
http://www.efc.be/programmes_services/resources/Documents/befc0644.pdf

Gaillard, J. C. (2010). Vulnerability, capacity and resilience: Perspectives for climate and development policy. Journal of International Development, 22, 218-232. DOI: 10.1002/ jid.1675.

GDRC (Global Development Research Center). (2009). SD features: Definitions. Retrieved August 20, 2012, from http://www.gdrc.org/sustdev/definitions.html

Hodge, S. (2010). Social consequences of climate change: Advocating multi-sectoral climate change education for child rights. Quality education, water and sanitation, health, nutrition and participation education section. Retrieved August 10, 2012, from http://unfccc.int/ files/cooperation_and_support/education_and_outreach/application/pdf/lac2010p06. pdf

IALEI (International Alliance of Leading Education Institutes). (2009). Climate change and sustainable development: The response from education. The recommendations from the International Alliance of Leading Education Institutes. Retrieved August 10, 2012, from http:// oldwww.dpu.dk/Everest/Publications/OmDPU\%5CInstitutter\%5CInstitut\%20for\%20 didaktik/20091211090537/CurrentVersion/Report\%20with\%20recommendations.final. dec09.pdf?RequestRepaired=true

Jonassen, D. H., \& Reeves, T. C. (1996). Learning with technology: Using computers as cognitive tools. In D. H. Jonassen (Ed.), Handbook of research for educational communications and technology (pp. 693-719). New York: Macmillan.

Jonassen, D. H., Peck, K. L., \& Wilson, B. G. (1998). Learning with technology: A constructivist perspective. Columbus, $\mathrm{OH}$ : Prentice-Hall.

Liang, X., \& Kim, C. (2004). Classroom assessment in web-based institutional environment: Instructors' experiences. Practical Assessment, Research \& Evaluation, 9(7). Retrieved August 12, 2012, from http://PAREonline.net/getvn.asp?v=9\&n=7

Liu, M. C., \& Wang, J. Y. (2010). Investigating knowledge integration in Web-based thematic learning using concept mapping assessment. Educational Technology \& Society, 13(2), $25-39$.

Makrakis, V. (2008). An instructional design module of ICT that empowers teachers to integrate education for sustainable development across the curriculum. In C. Angeli, \& N. Valanides (Eds.), Proceedings of the 6th Panhellenic Conference with International Participation on Information and Communication Technologies in Education: 1 (pp. 391398). Nicosia: University of Cyprus.

Makrakis, V. (2010). The challenge of WikiQuESD as an environment for constructing knowledge in teaching and learning for sustainable development. Discourse and Communication for Sustainable Education, 1(1), 50-57.

Makrakis, V. (2011). ICT-enabled education for sustainable development: Merging theory with praxis. In M. Youseef \& S. A. Anwar (Eds.), Proceedings of the 4th Annual Conference 
on e-Learning Excellence in the Middle East - in Search of New Paradigms for Re-engineering Education (pp. 223-232). Dubai: Hamdan Bin Mohammed e-University.

Makrakis, V. (2012). Critical issues for the course curricular design and development of post-graduate programmes. Proceedings of the International Forum "Modern Information Society Formation - Problems, Perspectives, Innovation Approaches" (pp. 85-107). Saint Petersburg: State University of Aerospace Instrumentation.

Makrakis, V., \& Kostoulas-Makrakis, N. (2012). The challenges of ICTs to online climate change education for sustainable development: The ExConTra learning paradigm. In S. A. Anwar (Ed.), Proceedings of the 5th Conference on eLearning Excellence in the Middle East - Sustainable Innovation in Education (pp. 594-605). Dubai: Hamdan Bin Mohammed e-University.

Ospina, A. V. (2012). The outcome of Rio+20: An ICT perspective on the "Future We Want". Retrieved August 28, 2012, from http://niccd.wordpress.com/

Ospina, A. V., \& Heeks, R. (2010). Linking ICTs and climate change adaptation: A conceptual framework for eresilience and eadaptation. Retrieved August 10, 2012, from http://www.niccd.org/ConceptualPaper.pdf

Plantilla, J. (2006). Human rights in education for sustainable development. Paper prepared for the UNESCO expert meeting on ESD: Reorienting education to address sustainability. Retrieved August 10, 2012, from http://www.unescobkk.org/fileadmin/user_upload/esd/ documents/workshops/kanchanburi/plantilla_humanrights.pdf

Puttnam, D. (2009). Climate change: What price will future generations pay? Retrieved August 10, 2012, from http://news.bbc.co.uk/2/hi/science/nature/8374965.stm

Ruxton, S. (2005). What about us? Children's rights in the European Union: Next steps. Retrieved July 25, 2012, from http://www.crin.org/docs/Ruxton\%20Report_WhatAboutUs.pdf

Sax, H. (2008). Child poverty - millennium development goals - rights of the child. Retrieved July 10, 2012, from http://www.entwicklung.at/uploads/media/Child_poverty_and_ MDG.PDF

Stone, L., \& Lofts, K. (2009). Climate change, child rights and intergenerational justice. IDS in focus policy briefing. Retrieved July 10, 2012, from http://www.ids.ac.uk/files/dmfile/ IF13.2.pdf

Tanner, T., Lazcano, J., Lussier, K., Polack, E., Oswald, K., Sengupta, A., Murphy, L., \& Rajabali, F. (2009). Children, climate change and disasters: An annotated bibliography. Retrieved September 10, 2012, from http://www.childreninachangingclimate.org/database/CCC/ Publications/CCC_Children-Climate-Disasters-Bibliography.pdf

Todaro, M., \& Smith, C. S. (2009). Economic development. Harlow: Pearson Education.

Trumpower, D., \& Shahzad Sarwar, G. (2010). Concept maps: Making learning meaningful. In J. Sánchez, A. J. Canas \& J. D. Novak (Eds.), Formative Structural Assessment: Using Concept Maps as Assessment for Learning. Proceedings of 4th International Conference on 
Concept Mapping (pp.132-136). Ottawa: University of Ottawa.

UN (United Nations). (1989). Convention on the rights of the child. Retrieved April 18, 2012, from http://www2.ohchr.org/english/law/crc.htm

UNESCO (United Nations Educational, Scientific and Cultural Organisation). (2009). Education for sustainable development and climate change. ED-2009/WS/10. Retrieved May 13, 2012, from http://unesdoc.unesco.org/images/0017/001791/179122e.pdf

UNICEF (United Nations International Children's Fund). (2003). The millennium development goals. They are for children. Retrieved September 10, 2012, from http://www.unicef.org/ publications/files/pub_mdg_en.pdf

UNICEF (United Nations International Children's Fund). (2009). The state of the world's children. Retrieved May 10, 2012, from http://www.unicef.org/rightsite/sowc/pdfs/ SOWC_Spec\%20Ed_CRC_Main\%20Report_EN_090409.pdf

UNICEF (United Nations International Children's Fund). (2012). A legally binding instrument. Retrieved May 14, 2012, from http://www.unicef.org/crc/

UNICEF IRC (United Nations International Children's Fund Innocenti Research Centre). (2008). Climate change and children. A human security challenge. UNICEF. Retrieved May 12, 2012, from http://www.unicef-irc.org/publications/pdf/climate_change.pdf

UNDP (United Nations Development Programme). (2007). Human development report 2007/2008 - fighting climate change: Human solidarity in a divided world. Retrieved May 12, 2012, from http://hdr.undp.org/en/media/HDR_20072008_EN_Complete.pdf

\section{Correspondence:}

Vassilios Makrakis, Professor of ICT in Education, University of Crete, Department of Primary Education. Email: makrakis@edc.uoc.gr 